\title{
Islamic Symbols on Political Messages in Newspapers in Riau (Study in Regional Head Election 2017)
}

\author{
Muhd Ar. Imam Riauan', Syukur Kholil ${ }^{2}$, Ahmad Thamrin Sikumbang ${ }^{2}$ \\ ${ }^{1}$ Universitas Islam Riau, Riau \\ ${ }^{2}$ Universitas Islam Negeri Sumatera Utara \\ imamriauan@comm.uir.ac.id
}

\begin{abstract}
This study seeks to find the process of constructing Islamic symbols in the political message of newspapers in Riau. The symbol of Islam in question is a symbol of Islam exposed by newspapers in Riau during the campaign of the regional head election of Pekanbaru City starting from October 26, 2016 to February 11, 2017. The theory used in this study is social construction theory, by Peter L .Berger and Thomas Luckmann. Peter L.erger who at the beginning of his development, this theory is a constructivist study in sociology to understand the interactions created by individuals as members of society in a continuous manner becomes a reality that is experienced together in social life. This research uses a constructivist approach to understand how the process of constructing Islamic symbols in political messages. The subjects of this study were 5 candidates for regional head of Pekanbaru City who were actively exposed by the media and used Islamic symbols in various campaign activities during the Campaign from 26 October 2016 to 11 February 2017. The object of the research was the construction of Islamic symbols exposed to newspaper in Riau. The results of this study indicate that the construction process is divided into two, namely the construction process that occurs because it is caused by the process of finding data and facts about the needs of the community and the construction process that appears as the identity of prospective regional heads.
\end{abstract}

Keywords : Symbols, Islam, Political Messages, Newspapers

\section{Introduction}

The ability of the newspaper Riau Pos and Tribun Pekanbaru in delivering information relating to the activities of the 2017 mayor candidate in the city of Pekanbaru is inseparable from the message conveyed by prospective mayors and prospective figures. The message delivered is packaged in such a way as to attract the attention of the public to choose when in the voting booth. The use of these symbols has an important role so that packaged messages must represent the representation of the community in the selector. And the symbol of Islam is one of the interesting symbols to use considering that the majority of Pekanbaru City residents are Muslim who also have a close connection with Malay culture which is also Muslim.

The role of Riau Pos and Tribun Pekanbaru became information providers. On the one hand the media can disseminate actual information to the public and on the other hand Pekanbaru Mayor candidates use the media as a promotional and campaign channel to introduce themselves and political ideas and ideas to the community in achieving political goals and interests and create a positive image for the candidate pair to attract sympathy society. The limited space for mass media to invite candidates for the Mayor of Pekanbaru who want to advance in a general election buy space in the mass media to convey political messages.

In the General Election of the Mayor of Pekanbaru, the first decree of four candidates for the Mayor of Pekanbaru was declared and aborted a candidate for the Pekanbaru Mayor who was proposed by the Indonesian Democratic Party of Struggle (PDI) and the United Development Party (PPP) namely Destrayani Bibra and Said Usman Abdullah who carried by PDIP (5 seats) and PPP Party (4 seats) with a total of 9 seats. The couple was declared not qualified because of indications of administrative violations. Four pairs of candidates who 
passed were composed of two individual candidate pairs and two candidate pairs carried out by political parties.

The four candidates who passed were paired individual candidates Syahril and Said Zohrin with a total support of 47,137 people. Then the candidate pairs Ramli Walid and Irvan Herman were carried by the Golkar Party ( 7 seats), PAN ( 5 seats), PKB (4 seats), Hanura Party (4 seats), and NasDem Party (3 seats) with a total of 23 seats. Furthermore, Firdaus in-cumbent candidate pair with Ayat Cahyadi was carried by the Democratic Party (6 seats), Gerindra Party (4 seats), and PKS (3 seats) with a total of 13 seats. And finally the pair of independent candidates Herman Nazar and Defi Warman had a total support of 50,251 people.

In its continuation, the unqualified couple appealed and in the end the Pekanbaru KPU plenary session announced that the pair Dastrayani Bibra-Said Usman Abdullah was set as a candidate for the 2017 Pilkada participants according to the minutes of changes in the Pekanbaru City Election Commission number 59 / Kpts / KPU-Kota 004.435265 / X / 2016 concerning the appointment of 2017-2022 candidates for Mayor and Deputy Mayor who were determined to follow up on the dispute over the Regional Head Election deliberations stipulated by Pekanbaru Election Supervisory Committee in accordance with Panwaslu recommendations Number: 01 / LP / RI-11/10/2016 concerning forwarding violations of election administration, and said Said Usman Abdullah (SUA) fulfilled the requirements as Candidate for Deputy Mayor of Pekanbaru 2017-2022.

Some preliminary observations made by researchers found that many Islamic symbols were used in political messages in Riau newspapers. Candidates for mayors present with Islamic symbols displayed in the clothing of candidates for regional heads, Islamic religious ceremonies followed by regional head candidates during the post-conflict local election campaign, Islamic symbols in political talks and political statements of candidates appearing in newspapers in Riau representing Symbols Islam.

Regional head candidates actively use Islamic symbols in newspapers. Whether intentional or unintentional they choose the symbol in a political message. The simultaneous post-conflict local election campaign will begin on October $26^{\text {th }}$ to February $11^{\text {th }} 2017$, thus the regional head candidates will use newspapers as a medium for their political message.

Yes connect words into sentences and paragraphs. Discourse expresses propositions, where complex symbols present an image of something. Langer also addresses the interests of non-discursive or presentational symbols. The most important events for humans are emotional and are best communicated through worship, art, music.

Instead symbols are used in a more complex way by making someone think about something separate from their presence. Symbols are human conceptualizations of things; a symbol is for something. Something that has conceptual meaning is a symbol that can explain certain concepts. In everyday life we use symbols to give an explanation of something we want to convey or we want to show to others.

Islamic symbols if associated with symbol theory can be explained that symbols are human conceptualizations of Islam displayed in political messages. The Islamic symbol used can make us think about something that is separate from the presence of the symbol. The symbol of Islam makes us think of certain concepts that are present in the political message of newspapers.

The symbol of Islam, we can explain the concept of Islam that is used in a message that is conveyed to other people. So that without providing a conceptually complete explanation, 
the audience who receives messages from the newspaper understands something that can be understood as a particular concept specifically related to Islam.

According to the shape, the symbols conveyed can be divided into two types, namely verbal symbols and nonverbal symbols. Verbal symbols in their use using language. Language can be defined as a set of words that have been structured so that it becomes a set of meaningful sentences. Language can help us to structure knowledge to be logical and easily accepted by others because after all the good idea, if it is not arranged according to the structure of the correct language, then a good idea will become chaotic. Language does not only share experience, but also shapes the experience itself. Without language, humans cannot think, language that affects one's perceptions and patterns of thinking.

In addition to verbal symbols, we must also pay attention to nonverbal symbols in a process of political communication. Verbar communication will always be followed by nonverbal symbols that function to strengthen the content of verbal messages that are conveyed using language.

According to Hafied Cangara, nonverbal symbols are usually made with sign language or silent language. Nonverbal symbols used in communication can be grouped into several forms including: Kinesik (body movements), body touch, sound intonation, eye movements, silence, posture, artifacts and visualization, color, time, logo, and sounds.

Symbols carry the concept to represent a sign that can represent objects that use the symbol. The symbol of Islam in political messages through newspapers is a symbol that explains self-conceptualization of candidates for regional heads and the development programs that will be carried out in leading the government when elected. The use of symbols is done to facilitate the delivery of certain concepts that can represent the regional head candidates who participated in the election campaign of regional heads in Riau.

In the context of symbols as figures of speech, Mihaela Mancas defines symbols as "the name of a conventionally chosen object to refer to all categories of objects, abstract ideas or dominant categories related to that object. Symbols consist of two main categories: A name that is always quoted from the meaning of a real object word and a term replacement by another who has a motivated character. Mihaela Mancas classifies symbols into three categories: Conventional symbols that are converted into poetry symbols, precise poetry symbols and obscure poetry symbols.

\subsection{Social Construction}

Social construction theory, began to be introduced by Peter L.erger and Thomas Luckmann. Peter L. Berger is a sociologist from the New School for Social Sciences, New York, while Thomas Luckman is a sociologist from the University of Frankfurt. At the beginning of its development, this theory was a constructivist study in sociology to understand the interactions created by individuals as members of society in a continuous manner into a reality experienced together in social life.

The term construction of social reality became famous since it was introduced by Peter L. Berger and Thomas Luckman through his book The Social Construction of Reality: A Treatise in the Sociological of Knowledge (1966). He describes social processes through their actions and interactions, where individuals create continuously a reality that is owned and experienced together subjectively.

The origin of the social construction of the philosophy of constructivism begins with cognitive constructive ideas. According to Von Glaserfeld, cognitive constructive 
understanding emerged in this century in the writings of Mark Baldwin which was widely deepened and disseminated by Jean Piaget. However, if traced, actually the main ideas of constructivism have actually been started by Giambatissta Vico, an epistemologist from Italy, he is the forerunner of constructivism.

Berger and Luckman began to explain social reality by separating understanding of reality and knowledge. Reality is defined as the quality contained in realities that are recognized as having existence which does not depend on our own will. Knowledge is defined as the certainty that realities are real and have specific characteristics. Berger and Luckman said that community institutions are created and maintained or changed through human actions and interactions. Although society and social institutions are objectively visible, but in reality they are all built in subjective definitions through an interaction process. New objectivity can occur through repeated affirmations given by others who have the same subjective definition. At the highest level of generality, humans create a world in universal symbolic meaning, namely a holistic view of life, which legitimates and regulates social forms and gives meaning to various lives. In other words Berger and Luckman said that there was a dialectic between individuals creating society and society creating individuals. This dialectical process occurs through externalization, objectivation, and internalization.

The dialectic takes place in three simultaneous moments. First, self-externalization (selfadjustment) with the sociocultural world as a human product. Second, objectivation, namely social interaction that occurs in an intersubjective world institutionalized or undergoes an institutionalization process. Whereas the third, internalization, is the process in which individuals identify themselves with social institutions or social organizations where individuals are members.

Through these three dialectical processes social reality in the form of a political message can be understood. It can be illustrated that we can know something that builds meaning in a political message by explaining the three elements of the dialectic.

First, the externalization stage is an important part of an individual's life and becomes part of his socio-cultural world. In other words, externalization occurs at a very basic stage, in one pattern of interaction behavior between individuals and the social products of the community. This process is meant to exist when a social product has become an important part of society which is needed at any time by individuals, so that social products become an important part of one's life to see the outside world. Thus this externalization stage takes place when social products are created in the community, then individuals externalize (selfadjustment) into their socio-cultural world as part of human products.

Second, the stage of objectivation of social products occurs in the institutionalized intersubjective world of society. At this stage a social product is in the process of institutionalization. Thus individuals do objectivity to social products, both creators and other individuals. The most important thing in objectivation is the making of significance, namely making signs by humans.

After being produced, both objects or languages as externalizing products become objective reality. In fact, he can face humans as producers of cultural products. Culture that has status as objective reality, exists outside of human consciousness, there is "there" for everyone. The objective reality is different from the subjective reality of individuals. It becomes an empirical reality that can be experienced by everyone.

Third, internalization. The process of internalization is more of a re-absorption of the objective world into consciousness in such a way that subjective individuals are influenced by 
the structure of the social world. The various elements of the world that have been objectified will be captured as symptoms of reality beyond their consciousness, as well as internal symptoms for consciousness. Through internalization, humans become the results of society. For Berger, the reality was not scientifically shaped, nor was something revealed by God. But on the contrary, it is formed and constructed. With this kind of understanding, reality has a dual / plural face. Everyone can have different constructs of reality. Every person who has certain experiences, preferences, education, and social or social environment will interpret the social reality with their respective constructions.

Theory explains that the interaction created by individuals as members of society continues to lead to a reality that is experienced together in social life. Social reality that explains the world in universal symbolic meaning is created through the process of social interaction. Which means that the social life of the community that is deepened by the community in interacting creates a symbol that becomes a comprehensive view of life, which legitimizes and regulates social forms and gives meaning to various aspects of human life. In other words Berger and Luckman said that there was a dialectic between individuals creating society and society creating individuals. This dialectical process occurs through externalization, objectivation, and internalization.

The symbol of Islam in the political message is understood by this theory is with a symbol that emerges through a social construction process that involves a dialectical process. Islamic symbols emerge through social interactions experienced by informants through externalization, objectivation, and internalization stages. With this process the symbol of Islam can be understood and known for its social implications.

Externalization Stage The symbol of Islam emerges and is understood by society through the process of interaction as part of the social and cultural world. Thus this process is a fundamental process of an individual interaction with social products that exist in society. This stage becomes an important thing that can provide an understanding for individuals to understand the outside world such as understanding the symbols of Islam and adjusting themselves to their social and cultural world.

The next stage is objectivation in the institutionalized intersubjective world of society. At this stage there is a process of making signs by humans. At the stage of signs relating to Islam created through the process of intraction. The symbol is formed because of interactions that occur in people's lives. The last stage, internalization. The process of internalization is more of a re-absorption of the objective world into consciousness in such a way that subjective individuals are influenced by the structure of the social world. So the concept of reality about the symbol of Islam is formed and embedded in the users of these symbols.

\subsection{Islam}

Religion can be defined as follows: 1) Recognition of the existence of human relations with magical powers that must be obeyed; 2) Recognition of the existence of supernatural powers that control humans; 3) Binding oneself to a form of life that contains an acknowledgment to a source that is outside the human being that influences human actions; 4) Trust in an occult power that gives rise to a certain way of life; 5) A system of behavior derived from supernatural powers; 6) Recognition of the obligations that are believed to originate from an occult force; 7) Worship of supernatural powers arising from feelings of weakness and feelings of fear of the mysterious forces found in the realms of humans; 8) The teachings that God revealed to humans through an apostle. 
Besides that in a religion there are five aspects contained in it. First, from the aspect of its origin, there is something that comes from God such as a divine religion, and there are those that come from thoughts such as religion or cultural religion. Second, the objective aspect is to provide guidance for life so that the world and the hereafter are happy. Third, the scope aspect is the belief in the existence of supernatural powers, the human belief that their welfare in this world and their life in the hereafter depends on the existence of good relations with supernatural powers, emotional responses, and the existence that is considered sacred. Fourth, the aspects of socialization, which are passed down from generation to generation. Fifth, the aspect of the source, namely kitap suci.

We can understand Islamic religion by looking at its definition based on the language and terms. In terms of language, Islam means safe, secure, and peaceful. From the word salima then it is transformed into an aslama form which means surrender, enter into peace.

\subsection{Political Message}

In a political communication process there are elements that cannot be separated from one another. And one of the elements contained in the communication process is the message. The message is the core of the communication object that must be sent from the communicator to the communicant to create the same meaning for each individual involved in the communication process.

Political communication according to McNair is purely talking about the allocation of public resources that have value, whether it is the value of power or economic value, officers who have the authority to give power and decisions in making laws or rules, whether legislative or executive, as well as sanctions. sanctions, whether in the form of gifts or fines.

Communication studies not only talk about power, but Doris Graber warns that political communication is not only rhetoric, but also includes language symbols, such as body language and political actions such as boycotts, protests and demonstrations. Thus Hafied Changara revealed that the notion of political communication can be formulated as a process of passing symbols or communication symbols that contain political messages from a person or group to others with the aim of opening insight or ways of thinking, and influencing attitudes and behavior of audiences who are political targets.

What is meant by a message in the communication process is something that is conveyed to the sender to the recipient. Messages can be delivered face to face or through communication media. Its contents can be in the form of science, entertainment, information, advice, or propaganda.

In political communication, political actors, candidates for regional heads, carry out the process of delivering messages, both for personal interests and the interests of the people in their constituencies by using symbols. This also means that in the process of political communication also involves political symbols used by political communicators to determine success in communication. For this reason, the creativity of political communicators is required to create symbols or symbols that can be used to achieve political goals, both personal and general goals.

Message is the essence of political communication. The message can be negative and can be positive depending on the perceptions and meanings that arise from the audience who receive and interpret the communication message conveyed. The strength of the message is also affected by how to wrap the message. Political messages are statements that are conveyed both in writing and unwritten, both verbally and nonverbally, hidden and openly whose contents contain political weight. For example political speech, party law, electoral law, political 
statements, articles or contents of books / brochures and newspaper, radio, television and internet news containing political and government reviews, political poetry, banners or billboards, political advertisements, propaganda, nerve warfare, the meaning of the logo, the color of the shirt or flag, the body language and the like.

Message is everything that is conveyed by someone in the form of a symbol that is perceived and accepted by the audience in a series of meanings. Human ability to create symbols proves that humans already have a culture that is high in communication, ranging from simple symbols such as sounds, signals, and colors to symbols that are modified in the form of signals through airwaves and light, such as radio, television, telegram, telex and satellite. Symbols are human creations that contain meaning so that they can be used in communication.

According to the shape, the symbols conveyed can be divided into two types, namely verbal symbols and nonverbal symbols. Verbal symbols in their use using language. Language can be defined as a set of words that have been structured so that it becomes a set of meaningful sentences. Language can help us to structure knowledge to be logical and easily accepted by others because after all the good idea, if it is not arranged according to the structure of the correct language, then a good idea will become chaotic. Language does not only share experience, but also shapes the experience itself. Without language, humans cannot think, language that affects one's perceptions and patterns of thinking.

In addition to verbal symbols, we must also pay attention to nonverbal symbols in a process of political communication. Verbar communication will always be followed by nonverbal symbols that function to strengthen the content of verbal messages that are conveyed using language.

\section{Research Methodology}

In this study researchers chose to use a constructivist approach. This is because researchers are finding out the pattern of construction in the use of Islamic symbols on the political message of newspapers in Riau. In addition, researchers also want to understand how the meanings and motives of using Islamic symbols in political messages.

The subjects of this study were 5 candidates for regional head of Pekanbaru City who were actively exposed by the media and used Islamic symbols in various campaign activities during the Campaign from 26 October 2016 to 11 February 2017. The object of the research was the construction of Islamic symbols exposed to newspaper in Riau.

\section{Discussion}

The construction process in the process of forming symbols in the Riau Pos newspaper on Pekanbaru post-conflict local elections was constructed based on several processes. One of the processes carried out is the Iqra 'process towards the condition of the nation that occurs at this time by the name of Allah. Therefore, in understanding this process is closely related to understanding God's commands through the Qur'an.

In addition to this, the process of constructing political messages occurs through the process of literacy as a planning process in development activities. This process is carried out as a process of the emergence of each communication symbol conveyed to the public both in the electoral process during the campaign and the process of running the government in the city of Pekanbaru. 
Literacy is used in the process of constructing Islamic symbols in the Pekanbaru postconflict local election. The literacy process in question is a comprehensive process.

\section{Conclusion}

Construction process The Islamic symbol used by regional head candidates exposed through newspapers in Rau is divided into two aspects, namely the construction process that occurs due to the process of finding data and facts about the needs of the people of Pekanbaru City and then used as a basis for issuing ideas development that will be offered and promised to the community during the campaign. Second, is the construction process that emerges as the daily identity of the regional head candidates who are Muslims who cause Islamic symbols to emerge spontaneously and be conveyed verbally and non-verbally during the campaign.

\section{References}

Abd. Aziz. 2009. Filsafat Pendidikan Islam. Yogayakarta: Sukses Offset.

Ardianto, Elvinaro \& Bambang Q-Anees. 2009. Filsafat Ilmu Komunikasi. Bandung: Simbiosa Rekatama Media.

Arifin, Anwar. 2011. Komunikasi Politik, Filsafat, Paradigma, Teori, Tujuan, Strategi, dan Komunikasi Politik Indonesia. Yogyakarta: Graha Ilmu.

Basrowie \& Suwandi. 2008. Memahami Penelitian Kualitatif. Cetakan pertama, Jakarta: PT Rineka Cipta.

Bungin, Buhan. 2008. Konstruksi Sosial Media Massa: Kekuatan Pengaruh Media Massa, Iklan Televisi, dan Keputusan Konsumen serta Kritik Terhdap Peter L.Berger \& Thomas Luckmann. Jakarta: Kencana.

Cangara, Hafied. 2009. Komunikasi Politik: Konsep, Teori, dan Strategi. Jakarta: Rajawali Pers . 2016. Komunikasi Politik: Konsep, Teori, dan Strategi Ed. Revisi. Jakarta: PT. Rajawali Pers

Firmanzah. 2008. Marketing Politik: Antara Pemahaman, dan Realitas. Jakarta: Yayasan Obor Indonesia.

Fisher, B. Aubrey. 1978. Teori-teori Komunikasi (Penyunting Jalaluddin Rakhmat), Bandung: Remadja Rosdakarya.

Hefni, Harjani. 2015. Komunikasi Islam. Jakarta: Kencana.

Herdiansyah, Haris. 2011. Metodologi Penelitian Kualitatif Untuk Ilmu-Ilmu Sosial. Jakarta: Selemba Humanika.

Kholil, Syukur, Komunikasi Islami, Bandung: Cita Pusaka, 2007.

Kriyantono, Rachmat. 2007.Teknik Praktis Riset Komunikasi.Kencana Prenada Media Group : Jakarta

Kuswarno, Engkus. 2008. Etnografi Komunikasi Pengantar dan Contoh Penelitiannya. Bandung: Widya Padjadjaran.

Littlejohn, Stephen W \& Karen A. Foss. 2007. Teori Komunikasi: Theories of Human Communication ed.9. Terj. Mohammad Yusuf Hamdan. Jakarta: Salemba Humanika. 2009. Teori Komunikasi. Terjemahan Mohammad Yusuf Hamdan. Jakarta: Salemba Humanika.

Nata, Abuddin. 2004. Metode Studi Islam. Jakarta: PT. Raja Grafindo Persada. 
Rohadi Abdul Fatah, ddk. 1997. Ilmu dan Teknologi Dalam Islam. Jakarta: Rineka Cipta.

Rohim, Syaiful. 2009. Teori Komunikasi Perspektif, Ragam, \& Aplikasi. Jakarta: Rineka Cipta. Thoha. 1996. Kapita Selekta Pendidikan Islam. Yogyakarta: Pustaka Pelajar Offset.

West, Richard \& Lynn H. Turner. 2009. Pengantar Teori Komunikasi: Analisis dan Aplikasi. Terjemahan Maria Natalia Damayanti Maer. Jakarta: Salemba Humanika.

Moleong, Lexy J. 2000. Metodologi Penelitian Kualitatif. Bandung: PT. Remaja Rosdakarya. 2009. Metodologi Penelitian Kualitatif. Bandung: Remaja Rosdakarya.

Mulyana, Deddy. 2008. Metodologi Penelitian Kualitatif: Paradigma Baru Ilmu Komunikasi dan ilmu sosial lainnya. Bandung: Remaja Rosdakarya

Rohim, Syaiful. 2009. Teori Komunikasi Perspektif, Ragam, \& Aplikasi. Jakarta: Rineka Cipta. Satori, Djam'an \& Aan Komariah. 2009. Metodologi Penelitian Kualitatif. Bandung: Alfabeta.

Subiakto, Henry \& Rachma Ida. 2012. Komunikasi Politik, Media, dan Demokrasi. Kencana Prenada Media Group: Jakarta.

Usman, Husaini. 2011. Metode Penelitian Sosial. Jakarta: Bumi Aksara.

Burhan Bungin, (2001). "Makna Realitas Sosial Iklan Televisi Dalam Masyarakat Kapitalistik,". Masyarakat, Kebudayaan Dan Politik, Th Xiv, No 2, April 2001, 51-64.

\section{Internet}

Pedersen, Elena Gagiu, 2015. Semantics of Symbol: Main Theories about the Symbol and the Themes of Symbol in Alexandru Macedonski's Poetry. Romania, Faculty of Education Science: Procedia - Social and Behavioral Sciences Vol.80, 2015, 586-592. https://www.sciencedirect.com/science/article/pii/S1877042815015104. Accessed on July $26^{\text {th }}, 2018$.

http://www.nielsen.com/id/en/press-room/2014/nielsen-konsumsi-media-lebih tinggi-di-luarjawa.html. accessed on December $26^{\text {th }}, 2018$

http://eastspring.co.id/dms/files/spring-of-life---april-2013_20130423184912.pdf （accessed on February $26^{\text {th }}, 2018$ ) 